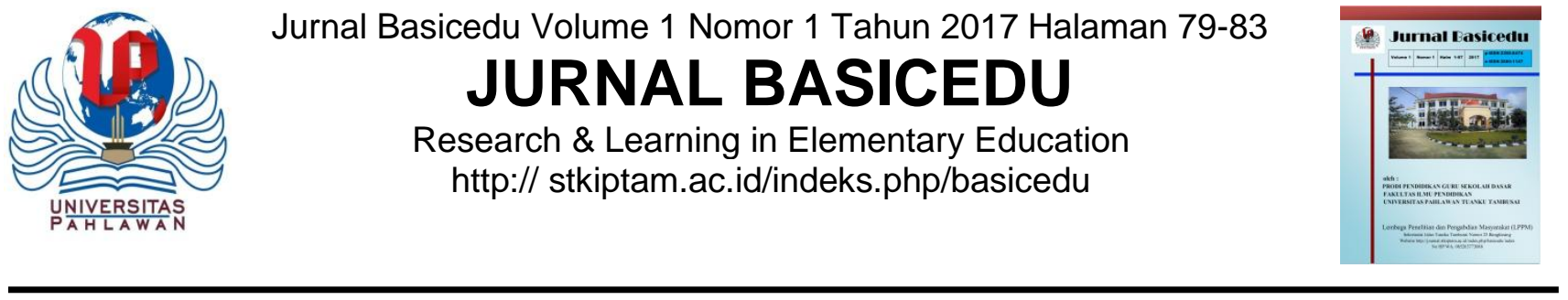

\title{
PERSEPSI ORANG TUA TERHADAP PENDIDIKAN INKLUSIF SEKOLAH DASAR DI KECAMATAN GUNUNG PUTRI KABUPATEN BOGOR PROVINSI JAWA-BARAT
}

\author{
Ahmad Waki ${ }^{1}$ \\ ${ }^{1}$ Fakultas Pendidikan Ilmu Pengetahuan Sosial, Prodi Bimbingan Konseling, \\ Universitas Indraprasta PGRI Jakarta \\ e-mail : unindra103@gmail.com
}

\begin{abstract}
This study aims to know parents perception toward the implemetation of inclusive education of elementary school in Gunung Putri Subdistric. This study used survey method. 26742 parents who spread into 92 elementary school in 2016 were taken apart as population of the research. The research sample were 394 parents in ten subdistric regency/ city Gunung PutriBogor. In collecting the data, the researcher employed open-ended questionnaire. The data were analysed using percentage formula. The research finding shows that $77.2 \%$ parents agree to the application of inclusive education in elementary school, whereas $25.8 \%$ parents disagree with performance of inclusive education in elementary school. The most reason agree on the implementation of inclusive education states that every child has the same rights, while the most reason that disagree with the implementation due to fear of negative impact when their children mixed with special needs children.
\end{abstract}

.Keywords: : parents perception, inclusive education, elementary school.

\begin{abstract}
Abstrak
Penelitian ini bertujuan untuk mengetahui persepsi orang tua terhadap implemetation pendidikan inklusif sekolah dasar di Gunung Putri Kecamatan. Penelitian ini menggunakan metode survei. 26.742 orang tua yang menyebar ke 92 sekolah dasar pada tahun 2016 diambil terpisah sebagai populasi penelitian. Sampel penelitian adalah 394 orang tua dalam sepuluh kabupaten Kecamatan Gunung Putri Bogor. Dalam pengumpulan data, peneliti memakai kuesioner terbuka. Data dianalisis dengan menggunakan rumus persentase. Hasil penelitian menunjukkan bahwa 77,2\% orang tua setuju dengan penerapan pendidikan inklusif di sekolah dasar, sedangkan 25,8\% orang tua tidak setuju dengan kinerja pendidikan inklusif di sekolah dasar. Alasan pelaksanaan pendidikan inklusif bahwa setiap anak memiliki hak yang sama, sedangkan alasan yang tidak setuju dengan pelaksanaansekolah inklusi karena takut dampak negatif ketika anak-anak digabung
\end{abstract}

Kata Kunci : orang tua persepsi, pendidikan inklusif, sekolah dasar 


\section{PENDAHULUAN}

Pendidikan merupakan salah satu hak asasi manusia yang dilindungi secara hukum baik secara internasional maupun nasional. Dalam skala internasional perlindungan terhadap pelaksanaan Pendidikan sudah tercetuskan pada tahun 1948 dalam deklarasi universal hak asasi manusia. Begitu pula dalam skala nasional, UUD 1945 pasal 31 .

Hal ini dipertegas dalam UU RI No. 20

Tahun 2003 tentang Sistem Pendidikan Nasional, serta dalam Permendiknas No. 70 tahun 2009 tentang tentang pendidikan inklusif bagi peserta didik yang memiliki kelainan dan memiliki potensi kecerdasan dan/atau bakat istimewa. Secara legal dapat dilihat bahwa pelaksanaan pendidikan memiliki keinginan yang kuat untuk dapat dilaksanakan secara adil dan menyeluruh tanpa adanya pengelompokan yang berdasarkan kekurangan yang dimilikinya.

Semangat kebersamaan inilah yang kemudian melahirkan sebuah pola pendidikan yang yang mengakomodasi semua anak tanpa mempedulikan keadaan fisik, intelektual, sosial, emosi, bahasa atau kondisi-kondisi lain, termasuk anak-anak penyandang cacat, anak (gifted children), pekerja anak dan anak jalanan, anak di daerah terpencil, anak kelompok etnis dan bahasa minoritas, anak yang tidak beruntung dan terpinggirkan dari kelompok masyarakat (Riska, 2010:71).

Pendidikan inklusif merupakan sauatu pendekatan pendidikan yang inovatif dan strategis untuk memperluas akses pendidikan bagi semua anak berkebutuhan khusus termasuk anak penyandang cacat. Dalam konteks yang lebih luas, pendidikan inklusif juga dapat dimaknai sebagi satu bentuk reformasi pendidikan yang menekankan sikap anti diskriminasi, perjuangan persamaan hak dan kesempatan, keadilan, dan perluasan akses pendidikan bagi semua, peningkatan mutu pendidikan, upaya strategis dalam menuntaskan wajib belajar, serta upaya merubah sikap masyarakat terhadap anak berkebutuhan khusus (Sunaryo, 2009:1).
Di Indonesia pendidikan inklusif telah mulai dilaksanakan di sekolah tertentu. Hal ini sesuai dengan adanya Surat Edaran Dirjen Dikdasmen no 380/C.66/MN/ 2003 tentang pendirian pendidikan inklusi di tingkat kabupaten/ kota. Meskipun definsi tentang pendidikan inklusif itu bersifat progresif dan terus berubah, namun tetap diperlukan kejelasan konsep yang terkandung didalamnya, karena banyak orang menganggap bahwa pendidikan inklusif sebagai versi lain dari pendidikan khusus/PLB (special education).

Konsep yang mendasari pendidian inklusif sangat berbeda dengan konsep yang mendasari pendikan khusus (special education). Inklusi atau pendidikan inklusif bukanlah istilah lain dari pendidikan khusus. Konsep pendidikan inklusif mempunyai banyak kesamaan dengan konsep yang mendasari pendidikan untuk semua (education for all) dan konsep tentang perbaikan sekolah (schools improvement).

Unesco (2005:13) mendefinisikan pendidikan inklusif bagian program pendidikan untuk semua (education for all), dinyatakan bahwa Inklusi dipandang sebagai proses menangani dan merespon keragaman kebutuhan semua peserta didik melalui peningkatan partisipasi dalam belajar, budaya dan masyarakat, serta mengurangi pengucilan dalam dan dari pendidikan. Hal ini melibatkan perubahan, modifikasi, pendekatan, struktur dan strategi, dengan visi yang sama mencakup semua anak dari rentang usia yang tepat dan dengan keyakinan bahwa itu adalah tanggung jawab semua untuk mendidik anak.

Di Indonesia pendidikan inklusi pendidikan yang mengikutsertakan anak berkebutuhan khusus belajar bersama dengan anak sebayanya di sekolah reguler yang terdekat dengan tempat tinggalnya. Penyelenggaraan pendidikan inklusif menuntut pihak sekolah melakukan penyesuaian baik dari segi kurikulum, sarana dan prasarana pendidikan, maupun sistem pembelajaran yang disesuaikan dengan 
kebutuhan individu peserta didik (Direktorat PSLB, 2004).

Namun pemahaman tentang seting pola pendidikan inklusi itu tampaknya belum bisa dijadikan patokan, karena pada kenyataanya masih banyak masyarakat yang belum memahami secara keseluruhan tentang konsep pendidikan inklusi. Sehingga peneliti merasa perlu untuk meneliti seberapa besar persepsi positif ataupun negatif orang tua terhadap pelaksanaan pendidikan inklusi di sekolah.

\section{Sarwono menjelaskan bahwa} (2010:93) persepsi berasal dari bahasa Latin perceptio; dari percipere, yang artinya menerima atau mengambil. Persepsi merupakan proses mengetahui atau mengenali objek dan kejadian objektif dengan bantuan alat indera. persepsi terkait dengan alat-alat indera, terutama indera penglihatan dan pendengaran (Chaplin, 2011:358). Persepsi dapat diartikan cara pandang seseorang terhadap suatu objek dan bagaimana ia mengartikan atau memaknai objek tersebut. persepsi orang tua siswa terhadap pendidikan inklusif akan menjadikan pelaksaan pendidikan berjalan baik atau tidak baik, mengingat orang tua merupakan stakeholder yang sangat penting dalam pengembangan sekolah. Peran orang tua sangqt penting dalam pembentukan pola pikir siswa disekolah

\section{METODOLOGI PENELITIAN}

Penelitian ini dilakukan dengan mengunakan metode survey deskriptif dengan pendekatan kuantitatif yaitu suatu penelitian yang mendeskripsikan secara sistematis, faktual dan akurat mengenai fakta-fakta dan sifat populasi tertentu atau mencoba menggambarkan fenomena secara detail. Adapun langkah-langkah dalam suatu penelitian survey deskriptif menurut Cohen et,el. (2007: 209).), yaitu: a). Definisikan tujuan. b). Tentukan jenis survei yang diperlukan. c). Merumuskan pertanyaan penelitian atau hipotesis. d). Tentukan isu-isu yang fokus. e). Tentukan informasi yang diperlukan untuk mengatasi persoalan ini. f).
Putuskan sampling diperlukan. g). Putuskan instrumentasi dan buat metric. h). Buat instrumen pengumpulan data.g). Tentukan bagaimana data akan dikumpulkan. h). uji coba instrumen. i). Proses Pengambilan data. j). Kumpulkan data. k). Analisis data. 1). Laporkan hasil.

Proses survey deskripsi ini dilakukan dengan bertahap. Mulai dari tahap mendefinisikan tujuan hingga pelaporan hasil. Pelaporan hasil dilakukan setelah mengolaj data yang sudah diambil di sekolah. Pengambilan data di sekolah memerlukan waktu yang cukup panjang. Hal ini dikarenakan adanya jadwal dan program sekolah yang berbeda-beda.

\section{Tabel 1. Jumlah Populasi}

\begin{tabular}{|c|c|c|}
\hline No & \multicolumn{2}{|c|}{ Desa /Orang tua Siswa } \\
\hline $\mathbf{1}$ & Wanaherang & 2507 \\
\hline 2 & Bojong Kulur & 4106 \\
\hline 3 & Ciangsana & 4073 \\
\hline 4 & GunungPutri & 2869 \\
\hline 5 & Bojong Nangk & 1607 \\
\hline
\end{tabular}

$\begin{array}{lcr}\text { 6. Tlajur Udik } & 3317 & \\ \text { 7. Cicadas } & 2753 & 7 \\ \text { 8. Cikeas Udik } & 907 & 5 \\ \text { 9. Nagrak } & 3851 & 11 \\ \text { 10. } \text { Kranggan } & 752 & 4\end{array}$

\begin{tabular}{lll}
\hline Jumlah & 26742 & 92 \\
\hline
\end{tabular}

Sumber Data : Kemendikbud 2016

Populasi dalam penelitian ini sebanyak 26742 orangtua yang tersebar kedalam 92 Sekolah Dasar. Pengambilan sampel pada penelitian ini dilakukan dengan menggunakan tekhnik Simple Random Sampling. Untuk menentukan jumlah sampel yang akan digunakan, maka dipakai rumus dari Taro Yamane (Riduwan, 2006:65).

$$
\mathrm{n}=\frac{\mathrm{N}}{1+\mathrm{N} \cdot d^{2}}
$$




$$
\begin{aligned}
& n=\frac{26742}{26742.0 .05^{2}+1} \\
& n=394
\end{aligned}
$$

Berdasarkan penggunaan rumus, tersebut, maka diperoleh jumlah sampel sebanyak 394 orang tua pada 10 desa/kelurahan di Kecamatan Gunung Putri Kabupaten Bogor. Teknik Penggumpulan data pada penelitian ini menggunakan angket. Data yang telah terkumpul akan dianalisis dengan cara deskripsi data tentang persepsi orang tua terhadap pendidikan inklusi padaorang tua siswa SD di Lampung dianalisis dengan menggunakan rumus persentase..

\section{HASIL DAN PEMBAHASAN}

Hasil penelitian mengenai persepsi orang tua terhadap pendidikan inklusi dipaparkan pada tabel 1 .

\section{Tabel 1. Hasil Persepsi Orang Tua Tentang Pendidikan Inklusi}

\begin{tabular}{llcr}
\hline NO & Desa / Kelurahan & Setuju & $\begin{array}{c}\text { Tidak } \\
\text { Setuju }\end{array}$ \\
\hline 1 & Wanaherang & $70 \%$ & $30 \%$ \\
2 & Bojong Kulur & $93 \%$ & $7 \%$ \\
3 & Ciangsana & $76 \%$ & $24 \%$ \\
4 & GunungPutri & $80 \%$ & $20 \%$ \\
5 & Bojong Nangka & $78 \%$ & $22 \%$ \\
6 & Tlajur Udik & $65 \%$ & $35 \%$ \\
7 & Cicadas & $69 \%$ & $31 \%$ \\
8 & Cikeas Udik & $77 \%$ & $33 \%$ \\
9 & Nagrak & $88 \%$ & $32 \%$ \\
10 & Kranggan & $76 \%$ & $24 \%$ \\
& & & \\
& & &
\end{tabular}

Berdasarkan Tabel 2 dapat diketahui bahwa sebanyak $77.2 \%$ orang tua setuju terhadap pelaksanaan pendidikan inklusi di SD, sedangkan $25.8 \%$ tidak setuju terhadap pelaksanaan pendidikan inklusi di SD. Desa/Kelurahan yang paling banyak menyetujui adanya pendidikan inklusi di SD ,desa Bojong Kulur dengan 93\% orang tua siswa dan Kabupaten yang paling banyak tidak setuju adanya pendidikan inklusi adalah desa Tlajur Udik sebanyak $65 \%$ tidak setuju terhadap pendidikan inklusi.

Didapatkan hasil bahwa alasan setuju terhadap pelaksanaan pendidikan inklusi terbanyak menyatakan setiap anak memiliki hak yang sama, sedangkan alasan tidak setuju terhadap pelaksanaan pendidikan inklusi terbanyak dikarenakan takut anak mereka berdampak negatif jika dicampurkan dengan anak berkebutuhan khusus.

Kenyataan menunjukkan bahwa perspekstif secara umum masyarakat terhadap pendidikan inklusif baik, namun pendidikan inklusif belum dapat diterapkan secara menyeluruh. Sehingga pemerintah diharapkan dapat memberikan langkah-langkah konkrit untuk dapat mengimplementasikan secara menyeluruh pada sekolah di Indonesai.

Hal pertama yang perlu dibenahi adalah permasalahan sumber daya manusia (SDM) guru. Sebagaimana dikemukakan dalam Peraturan Menteri Pendidikan Nasional Nomor 70 Tahun 2009 tentang Pendidikan Inklusif yang mewajibkan pemerintah kabupaten/kota menyediakan paling sedikit satu GPK pada satuan pendidikan yang ditunjuk. Selain itu, untuk meningkatkan kompetensi di bidang pendidikan khusus bagi pendidik dan tenaga kependidikan pada satuan pendidikan serta penyelenggara pendidikan inklusif, dan dalam hal ini pemerintah provinsi wajib membantu tugas-tugas tersebut (Pasal 10). Dalamimplementasinya, masih terdapat kekurangan guru, terutama GPK. Inilah yang menjadi masalah utama penerapan pendidikan inklusif (Handayani dan Rahadian, 2013: 41).

Selain itu kurikulum merupakan hal yang harus dibenahi juga, pendidikan inklusif mempunyai kurikulum yang relative fleksibel. Akan tetapi dalam realitasnya selama ini terdapat kurikulum yang tersusun kaku dan kurang tanggap terhadap kebutuhan anak yang berbeda. Meskipun pendidikan inklusif tidak mensyaratkan kurikulum yang terpisah, antar 
siswa namun kurikulum pendidikan inklusif harus masuk dalam kurikulum arus utama dengan sifat yang lebih fleksibel (Handayani dan Rahadian, 2013: 42).

\section{SIMPULAN}

Berdasarkan penelitian didapatkan hasil bahwa perspekstif orang tua siswa terhadap pendidikan inklusif baik, alasan setuju terhadap pelaksanaan pendidikan inklusi terbanyak menyatakan setiap anak memiliki hak yang sama, sedangkan alasan tidak setuju terhadap pelaksanaan pendidikan inklusi terbanyak dikarenakan takut anak mereka berdampak negatif jika dicampurkan dengan anak berkebutuhan khusus. Pendidikan inklusif belum dapat diterapkan secara menyeluruh. Sehingga pemerintah diharapkan dapat memberikan langkah-langkah konkrit untuk dapat mengimplementasikan secara menyeluruh pada sekolah di Indonesia.

\section{DAFTAR PUSTAKA}

Anwar Chairul 2017.Teori-Teori Pendidikan.Yogyakarta:Ircosod

Chaplin J.P. (2011). Kamus Lengkap Psikologi. Terjemahan oleh Kartini Kartono. Jakarta: PT. Rajagrafindo Persada.

Cohen et,el. (2007). Research Methods in Education. New York: Routledge.

Direktorat PSLB. (2004). Pedoman Penyelenggaraan Pendidikan

Inklusif (Buku Paket). Jakarta:

Direktorat PSLB.

Handayani, Titik dan Rahadian, Angga Sisca. (2013). Peraturan Perundangan dan Implementasi Pendidikan Inklusif. Jurnal Masyarakat Indonesia, Volume 39, No. 1.

Permendiknas No.70,tentang Pendidikan Inklusif Bagi peserta didik yang Memiliki Kelainan dan bakat

Riduwan.2006.Metode dan Teknik Menyusun Tesis.Bandung:Alfabeta

Riska Ahmad. (2010). Memaknai Dan

Mengembangkan Keberagaman Peserta Didik Melalui Pendidikan
Pedagogi: Jurnal ilmiah ilmu pendidikan. Vol. X No. 2. Hal. 70-75.

Sarwono, Sarlito Wirawan. (2010). Pengantar Psikologi Umum Jakarta: Rajawali Press.

Sunaryo. (2009). Menejemen pendidian inklusif. Repostoru UPI. Tersedia di .http://a-research.upi.edu/(diakses tanggal 15 Desember 2016).

Undang- undang Dasar 1945.

Undang- undang No. 23 tahun 2003 tentang Sistem Pendidikan Nasional. Jakarta:Depdinas

UNESCO. (2005). Guidelines for Inclusion: Ensuring Access to Education for All. Paris: United 